\title{
Remaining on the Same Side of the River: A Critical Commentary on Paulo Freire's Later Work
}

\begin{abstract}
"He was concerned with the number of persons who let themselves be deceived by neo-liberal slogans and so become submissive and apathetic when confronted with their former dreams. Paulo used a metaphor for this situation: 'They have gone to the other side of the rivir!".

Ana Maria (Nita) Araújo Freire
\end{abstract}

\section{INTRODUCTION}

In a period dominated by neoliberal discourse. in which it has become unfashionable to dream of a world that is different from and better than the present one, many of us still find refuge and solace in the work of Paulo Freire. Remaining steadfast, till the very end, to his cherished principles of radical humanization and democracy. Freire continued to produce work that provides resources of hope, agency and reinvigoration. To many of us cultural workers, engaged in a constant search for emancipatory possibilities, his work stands as a crag of sanity facing the contemporary tide of nihilistic madness.

\section{FACTORS INFLUENCING LATER WORK}

The fatalism brought about by neoliberalism is one of several factors that influenced Freire's later output in what is a very large oeuvre. There were, of course, other important factors which influenced his later work. These include his involvement 
as founding member of the Partido dos Trabalhadores (PTWorkers' Party) in Brazil and his work as Education Secretary in São Paulo after the Party won the municipal elections there. One other significant factor was the emergence of important social movements in Brazil, especially the Movimento dos Trabalhadores Rurais Sem Terra. ${ }^{2}$ This is arguably one of the two most vibrant movements in Latin America, the Frente Zapatista in Chiapas being the other. The MST is located in the impoverished Nord-Este (the North East) where a particular form of "slave labour" (involving displacement of "day workers") is common. The Movement allies political activism and mobilization with important cultural work, including highly inspiring music and poetry. ${ }^{3}$ As in the period which preceded the infamous 1964 coup. Freire's work and thinking must also have been influenced and reinvigorated by the growing movement for the democratization of Brazilian society. Only a few days before his death, he stood enthralled at the huge MST march into Brasilia. ${ }^{4}$ There was also his marriage, following a period of desolation caused by the death of his beloved Elza, to Dr. Ana Maria (Nita) Araújo Freire, his former student, fellow academic and daughter of Paulo's teacher. Like Elza, Nita contributed to his output. An accomplished scholar in her own right, she often provided important editorial work. in the form of detailed and illuminating annotations. These annotations contribute to the reader's (particularly the non Brazilian reader's) understanding of the contexts that gave rise to the ideas in question. The later period of Freire's life also included collaborative projects with international scholars and activists, especially key figures in the North American critical pedagogy movement.

\section{THE WATERSHED}

It is very difficult and arbitrary to establish a cut off point in order to indicate the later period of Paulo Freire's works. There are those who would argue that, as far as his English texts go, the Politics of Education, ably translated by Donaldo Macedo (Freire, 1985), and the conversational text with Ira Shor (Shor and Freire, 1987), represent a watershed. Ideas which were implicit in his early work, including his most celebrated 
work Pedagogy of the Oppressed, were revisited and developed further in these books (see Allman et al., 1998, p. 9). One of these two books (Freire. 1985) is a compendium of old and new pieces. It includes. for instance, the early "Adult Literacy Process as Cultural Action for Freedom" alongside a highly illuminating conversation with Donaldo Macedo. For heuristic purposes, I shall concentrate, in the rest of this essay, on those works published in the last seven years of Paulo's life. These are works published in the nineties. Of course, there will be passing references to and quotes from earlier works, since many of the ideas recur throughout Paulo's writings.

\section{THE NINETIES}

The work of the nineties start off with a continuation of his "talking books" series. The first book, edited by Brenda Bell, John Gaventa and John Peters. involves a conversation between Freire and one of North America's much respected radical educators, Myles Horton of the Highlander Folk School (Horton and Freire, 1990). This is followed by the book marking the period in which Paulo Freire served as Education Secretary in São Paulo during Mayor Luiza Erundina de Souza's term of office. The book is aptly entitled Pedagogy of the City (Freire, 1993) which includes interviews and a fine postscript by his close collaborator, Ana Maria Saul. His work as Education Secretary was also documented in other places, including a taped 1991 AERA session in Chicago and studies by Ana Maria Saul. Carlos Alberto Torres, Pia Wong. Maria del Pilar O'Cadiz and Moacir Gadotti (see Torres, 1994. 1995; Gadotti, 1994; O'Cadiz et al. 1997). These were followed by the largely autobiographical. Pedagogy of Hope (1994) and Letters to Cristina (1996), both providing the reader with an expanded and often detailed knowledge of the concrete contextual background to the genesis and development of his ideas. These expositions of the context in which Freire's work was immersed, bring to the fore the various personalities and movements that played or are still playing an important role in the larger struggle for the democratization of Brazilian society. We learn of the group of Brazilian exiles in Chile and their Chilean counterparts who engaged in discussions that were 
central to the development of Pedagogy of the Oppressed.... Plinio Sampaio, Paulo de Tarso Santos, Marcela Gajardo, Ernani Fiori.... (Freire, 1994, p. 62). We learn of Paulo's childhood dreams and nightmares, about the stark reality of oppression, and not just the pain of exile but also the brutality and bestiality of torture. We learn of the publication of such key works as Brasil Nunca Mais (Brazil Never Again), published after Argentina's Nunca Mas ${ }^{5}$-a strong reminder of the coercive, apart from the ideological/consensual, basis of power. We learn of the courage of such radical ecclesiastics as the inspirational Paulo Evaristo Arns, incidentally the person who, following the abertura, visited Freire in Geneva to convince him to return to his homeland.$^{6}$ Brasil Nunca Mais was prepared under the auspices of Cardinal Arns. ${ }^{7}$ This is an account of the horrors of torture by the military regime, details of which are provided by Nita Freire in an extensive footnote in Letters to Cristina (Freire, 1996). We also hear about the courageous activism of other key figures such as the Nobel prize nominee, Betinho (Herbert Jose de Souza) who died the same year as Paulo (see Martin, 1998). He started a very important social movement in Brazil, the "Movement of Citizens' Action against Hunger and Misery and for Life." (Araújo Freire, in Freire, 1996, p. 247). To these one can add the lay dominican popular educator/journalist/activist, Carlos Alberto Libanio Christo, better known as Frei Betto. He is the co-author with Freire (and Ricardo Kotscho) of a splendid conversational book in the mid-eighties which, in my view (I read the Italian version), deserves to be translated into English (Freire and Betto, 1985 or Betto and Freire, 1986). These figures and many others convey to us the sense of a large movement for democratization in Brazil, of which Paulo Freire was just one, albeit key, representative.

Around the same time as Pedagogy of Hope, SUNY Press published a book length exchange between Paulo Freire and a group of scholars from UNAM, the National Autonomous University of Mexico (Escobar et al., 1994). This is a most interesting work focusing on a variety of topics, including, as the title suggests, the role of institutions of higher education. A related issue is that concerning the role of intellectuals operating as cultural workers in both the academic and public spheres. In between these two 1994 books and Letters to 
Cristina, we saw the publication of such books or booklets as Paulo Freire at the Institute (de Figueiredo-Cowen and Gastaldo, 1995) and Education and Social Change in Latin America (edited by Carlos Alberto Torres, 1995) which included pieces (interviews, talks, responses to discussants) by Freire. Significant papers such as an exchange with Carlos Alberto Torres in a book on Freire edited by Peter McLaren and Colin Lankshear (1994) and exchanges with Donaldo P. Macedo, in McLaren and Leonard (1993), Harvard Educational Review (1995) and most recently Steiner et al. (2000), were also produced. I would also refer, for good measure, to an interview with Carlos Alberto Torres in a book dealing with biographies of leading, predominantly North American, academics (Torres, 1998). Around the time of his death, we saw the publication of Pedagogy of the Heart. Later, Teachers as Cultural Workers, Letters to Teachers Who Dare Teach (1998a) and Pedagogy of Freedom (1998b) were published. The latter is the English version of the much acclaimed Pedagogia da Autonomia: Saberes necessários à prática educativa. We await the publication of Ideology Matters (with Donaldo Macedo).

\section{HOW MUCH IS LOST IN TRANSLATION?}

All the above books are in the English language, often translations of works originally written by Paulo Freire in Portuguese. Those who read his works in English must keep in mind that this is only a part, albeit a substantial one, of Freire's later output. Some still await translation. We also have to ask ourselves an important question: How much is lost in translation? Carmel Borg and I posed the question, in an interview, to Paulo's widow. Nita. She replied unequivocally that those who read Paulo only in translation miss much of the beauty and emotional resonance of his work.

He used words of such beauty and plasticity, organized in phrases and these in turn in the context of the totality of the text, with such aesthetic and political force that, I repeat, they cannot be transposed so easily into other languages because a language cannot be translated literally. And it is important to emphasize that his language is extraordinarily beautiful, rich and full of his particular way of being. . . Another problem for translators who did not know Paulo well is the fact that his language 
is loaded with his feelings, since he never provided a dichotomy between reason and emotion. Paulo was a radically coherent man: what he said contained what he felt and thought, and this is not always easy to translate. There are emotions whose meaning can only be well perceived, understood and felt inside a certain culture. And we Brazilians are unique in this way. I think this is so, isn't it? Without any prejudice, I think it is difficult for translators who have only studied the Portuguese language, albeit accurately, to express Paulo in all his aesthetic and even cultural-ideological richness. ${ }^{8}$

The emphasis on Freire's constant fusion between reason and emotion ought to be noted. Many of us experience this sense of an absolute fusion between the two human elements even when reading Freire in translation. I had stated, a year before our interview with Nita in São Paulo, that Freire has communicated with me both at an intellectual and emotional level (Mayo, 1997a. p. 369; Mayo, 1997b, p. 121). ${ }^{9}$ One can imagine how great our sense of this fusion would be if we read Paulo in the beautiful Brazilian variant of Portuguese. And yet I have come across a few North American feminists who refer to the "separation between reason and emotion" as one of the problematic polarities in Freire's work. There are those who would argue that his work promotes the rational to the exclusion of other domains of experience and knowing. One wonders whether they would hold the same opinion were they to read him in the original.

\section{WHAT IS NEW IN FREIRE'S LATER WORKS?}

I would argue that, in his later work, Freire stresses and elaborates on points which were already present in his early work. In a collaborative piece (Allman et al., 1998), it was argued that "these positions were also revised in the light of the new experiences of oppression and emancipation to which he was exposed in the later years of a highly eventful life as educator, activist, consultant to revolutionary governments (Guinea Bissau, Nicaragua, Grenada) and ultimately educational policy maker and administrator. His life was lived across different borders and different geographical contexts" (p. 9). Very few, if any, of his later works have that "unity of dialectical thought and style" (Allman et al., 1998, p. 10) which 
remains the distinctive feature of Pedagogy of the Oppressed. This having been said, it would be foolish to attempt to do justice to Freire's work and ideas by referring only to this celebrated piece. Freire was, like most critical intellectuals, a "person in process" constantly in search of greater coherence.

He has offered us ideas and conceptual tools which constantly warrant further elaboration, in view of the new experiences and challenges encountered across different borders. These experiences and challenges shed new light on Freire's concepts. Some elements which are considered to be central to the Freirean concept of "authentic dialogue" are re-visited and given expanded treatment in later works. Take the basic concept of "Listening". To engage in dialogue, educators must stop suffering from "narration sickness" and become "listeners". This, we would assume, is basic to a Freirean conception of teaching. For how can one engage in genuine dialogue without being able to listen, to resist the urge to speak (as Freire puts it)? Otherwise, one would be simply talking past the other. And yet, I would still find refreshing Freire's and Nita's illuminating reflections on the notion of "listening", in Pedagogy of Freedom and Convergence (Araujo Freire, 1998, pp. 4, 5) respectively:

\footnotetext{
Listening is an activity that obviously goes beyond mere hearing. To listen, in the context of our discussion here, is a permanent attitude on the part of the subject who is listening, of being open to the word of the other, to the gesture of the other. to the differences of the other. This does not mean, of course that listening demands that the listener be "reduced" to the other. the speaker. This would not be listening. It would be self annihilation. (Freire, 1998b. p. 107).
}

Works like Pedagogy of Freedom abound with reflections on some of those concepts or themes which recur throughout Paulo's oeuvre, including "Methodological Rigor", "praxis" ("critical reflection on practice"), "Respect for what students know", "Risk," "autonomy and dignity" and "agency" (the "Conviction that Change is possible" and the notion that we are conditioned but not determined beings). One finds new meanings, experiences new sensations and discovers new sources of inspiration each time one rereads a piece of good poetry. Likewise. one discovers new sensations, new meanings and fresh sources of inspiration when being led by Freire himself and Nita to revisit some of the basic concepts in the Freirean pedagogical approach. 
One cannot help being struck by the emotional impact of the following evocative account by Nita, again focusing on the basic concept of Listening. Like Paulo, Nita captures the tactility of the experience involved, fusing reason with emotion. And here we experience this only in translation!

\begin{abstract}
..Paulo's act of touching while looking at people made the act of touching, an act so natural in our Brazilian culture, more than body to body contact. Touching with his hand and with his look, Paulo somehow connected his whole being, his reason and emotion, to the whole being of another... His ability to listen, not just to hear the other person, but that way of listening mentioned in the Pedagogy of Autonomy [Pedagogy of Freedom-author's insertion]-also noticeable in his look signalled the moment when he accepted and gathered within himself what he was hearing from the other.... In Paulo, to touch, to look and to listen become moments of me and you in dialogue about something which he and the other person wanted to know. (Araújo Freire, 1998, pp. 4, 5).
\end{abstract}

Similar basic concepts are resorted to, elaborated on and refined not just by Paulo and Nita but also by many cultural workers and researchers who draw on Freire when grappling with a variety of phenomena. The idea of praxis and of "reading the word and the world" is taken up by others within the context of, say, "redemptive memory" (see McLaren and Da Silva, 1993; Mayo, 1999, pp. 147-151). In this context, the codification is the means to recuperate collective histories. After all, the collective process of praxis involved within a cultural circle entails a critical engagement with historically accumulated concepts and practices (Mayo, 1999, p. 147; Mayo, 1996, p. 156) ${ }^{10}$ And the same applies to many others who, like Freire, resort to these concepts to reinvent them within such areas as cultural studies, community theatre, feminist and anti-racist pedagogy, anti-colonial pedagogy and even such unlikely areas as museum studies (this involves the quest to transform traditionally colonizing spaces into decolonizing ones). The list is by no means exhaustive.

Furthermore, the explications and re-formulations of positions already present in his early work were probably rendered necessary because of the constant misappropriations of his ideas. Misconceptions concerning Freire abound, the sort of misconceptions that irked Paulo Freire and led him, after 1987, to stop using such terms as conscientização. He claims to have used it, for the last time, in a Geneva seminar with 
Ivan Illich (Freire. in Escobar et al., 1994, p. 46). He felt that the term had been bandied about freely and in a loose manner. As a result, it gradually lost its significance (Freire. 1993, p. 110; Freire, in Escobar et al., 1994, p. 46).

The assumed non-directiveness of a genuinely democratic education is another misconception which was strongly refuted by Freire. His insistence on the directiveness of education is, in fact, a recurring theme in his later works (see, for instance, Freire, in Freire and Macedo, 1995, p. 394). It was already emphasised in works published in the mid and late eighties, The Politics of Education (1985) and the conversational book with Ira Shor, Pedagogy for Liberation. Dialogues on Transforming Education (1987), being cases in point. The idea that a non-neutral education has, perforce, to be directive was, however, already implied in his earlier work, most notably his much celebrated Pedagogy of the Oppressed. What later works do is explicate this position further, also in view of many criticisms levelled at Freire's work, often based on a misconception of his position in this regard. Take Frank Youngman (1986) as an example. In an otherwise masterly contribution to the historical materialist literature in adult education, " Youngman provides a critique of Freire's pedagogy which is analysed within the context of its potential suitability or otherwise for a socialist pedagogy. In my view, he seemed bent on lopping off the feet that would not fit his Procrustean bed fa set of abstracted concepts for a Marxist education). He maintains that Freire is "ambivalent about saying outright that educators can have a theoretical understanding superior to that of the learners" (p. 179). Freire might not have said this outright in his early work but this is certainly implied in his contention that education is not neutral and that educators/activists must ask themselves on whose side are they when they teach/act. Furthermore, in books published around the same time that Youngman's work saw the light, Freire wrote explicitly that educator and learner are not on an equal footing: "Obviously we also have to underscore that while we recognise that we have to learn from our students... this does not mean that teachers and students are the same. I don't think so. That is, there is a difference between the educator and the student. This is a general difference. This is usually also a difference of generations" (Freire, 1985, p. 177). Shortly after, 
he would tell Ira Shor: "At the moment the teacher begins the dialogue, he or she knows a great deal, first in terms of knowledge and second in terms of the horizon that he or she wants to get to" (Freire, in Shor and Freire, 1987, p. 103).

These writings seem to have been overlooked in a number of studies on Freire. Paul V. Taylor's book length study on Freire's texts is a case in point (Taylor, 1993). Had he been familiar with these works, Taylor would probably have refrained from including the following statement (see Mayo, 1993, p. 283) in his otherwise in-depth and insightful analysis of Freire's de-codification process: "The most obvious (contradiction) is the overtly directive manner of the teaching. There is no hint here of a learning partnership, of a dialogue between equals. Rather, what is evident is the clear distinction between the teacher and the taught" (Taylor, 1993, p. 129). What we are presented with here is yet another formulation based on the common misconception that Freirean pedagogy is nondirective and involves a "dialogue among equals". And there is no mention of Freire's emphasis on directivity and the need to "teach" in another book length analysis of Paulo Freire's work, that by John Elias (Elias, 1994). If anything, the author reminds us, as a criticism of Freire, that there are "areas which entail careful teaching and even testing" (Elias, 1994, p. 116). So these important misconceptions concerning the nature of Freirean pedagogy abound even in full book length studies on Freire. In my view, these studies deserve to be consulted, since they have their strengths. ${ }^{12}$ However, for a more accurate and up to date explanation of Freire's pedagogical approach, one which does justice to Freire's actual thought, I would strongly recommend the introductory book by Freire's companion, Moacir Gadotti (Gadotti, 1994). Another full length study of Freire's work, by the New Zealand scholar, Peter Roberts (Roberts, 2000), is eagerly awaited.

One term which is dropped from the Freirean lexicon-it was probably never used by Freire but only by commentators, including yours truly-is that of "facilitator". Freire categorically refutes this term, in an illuminating exchange with Macedo (1995), because of its connotation of laissez faire pedagogy. "Teacher" is the term used. This comes across quite strongly in his series of letters to teachers "who dare teach" (Freire, 1998a). Teachers are presented as people who need 
to be competent, who teach when necessary, at times being 50 percent a traditional teacher (when circumstances warrant this-Freire in Horton and Freire, 1990, p. 160) and who require opportunities for ongoing teacher formation as well as professional recognition (which includes the provision of adequate pay).

This brings us to one important contribution that Freire's later work has made. The one book I would single out here is: Teachers as Cultural Workers: Letters to teachers who dare teach (1998). This is one of the finest books in English in Freire's later output, an output which, alas, is characterised by too much repetition (one gains the impression that, latterly, Freire produced one book too many). It is a pity that the book has been published only in hardcover. A paperback version would render the book more accessible and therefore an important source for prospective teachers undergoing preservice preparation as well as teachers currently in service. What this book places on the agenda is that there is no contradiction between a Freirean approach to an authentically dialogical education and the quest for professional recognition. By professional, Freire is not referring to the excesses of the "ideology of professionalism", based on the trait model of professionals, which often result in the following arrogant posture: I know what's best for you. Freire is using "profession" in the sense of people who are competent. both in terms of the subject matter taught and in terms of pedagogical disposition, and who engage in very important work which demands respect and adequate remuneration. He obviously has in mind the plight of teachers in the Brazilian public school system. Freire worked hard as Education Secretary to improve the conditions of underpaid teachers in São Paulo during Mayor Erundina's tenure. For Freire, teachers were not to be regarded as coddling aunts or mothers, a position which can sound problematic in that it somehow smacks of a machista devaluation of what has often been termed a "femninised profession" (see Fischman, 1999. pp. 557, 558). Equally problematic is his reference to the fact that teaching proves attractive to women during the short period of their working life prior to marriage (Freire, 1998a, p. 36). Unfortunately, Freire raises this issue without any engagement, on his part, in a critique of the normalising discourse, regarding women's role in the 
family, generated by and supporting the existing patriarchal structures of economic oppression. This is, after all, a discourse that continues to limit women's involvement in the public domain since it continues to channel them, for the greater part of their working life, into the domestic sphere. In this so called "post-Fordist" period, the domestic sphere also constitutes an important site for casualised work. It is therefore a normalising discourse that limits women's chances of embarking on a career rather than simply a job.

Freire regarded teachers not as coddling figures but as people who are engaged in work that necessitates the delicate balancing between freedom and authority, to which an entire section is devoted in Pedagogy of Freedom. And this brings me to what strikes me as an important theme in Freire's later work - a point which, in my view, was implied in his early work but was rendered more pronounced in his later ones. The issue of authority and freedom is broached time and again in Freire's works (see, for example. Freire, 1998a, p. 88; Freire, 1998b, pp. 95-99). Indeed, such repetition is necessary. Witness Diana Coben's (1998) insistence on a fundamental "contradiction" in Freire's work where dialogue and democratic social relations are preached while it is always the teacher who "holds the cards" (p. 186).

What is the alternative to this? Laissez faire pedagogy? This, as I have argued, is pedagogical treachery of the worst kind which often results in the violence meted out to learners by members of an "in-group" in possession of the required cultural capital allowing them to abuse a pseudo-dialogical process (Mayo, in McLaren and Mayo, 1999, p. 402). Freire has been arguing, at least since his book with Shor, for an authentically dialogical process in which the teacher has authority, deriving from his or her competence, and the respect generated by this competence "Teachers maintain a certain level of authority through the depth and breath of knowledge of the subject matter that they teach." (Freire, in Freire and Macedo, 1995, p. 378). This however does not degenerate into authoritarianism (Freire, in Shor and Freire, 1987: 91; Freire in Horton and Freire. 1990, p. 181; Freire, 1994, p. 79).

The educator's "directivity" should not interfere, in Freire's view, with the "creative, formulative, investigative capacity of 
the educand", for, if this were to be the case, this directivity degenerates into "manipulation. into authoritarianism" (Freire, 1994, p. 79). Stanley Aronowitz forcefully states, in his brilliant introductory essay to Pedagogy of Freedom, that "... the educator's task is to encourage human agency, not mold it in the manner of Pygmalion." (Aronowitz, 1998, p. 10). The position regarding "authority and freedom" has uncanny similarities with that expressed by Gramsci in his piece on the Unitarian School. where he calls for a balance to be struck between the kind of authority promoted by the old classical school (without the excess of degenerating into authoritarian education) and the freedom put forward by proponents of the Rousseau school. The latter school, for Gramsci. had to develop from its romantic phase (predicated on unbridled freedom for the learner, based on her or his spontaneityl and move into the classical phase, classical in the sense of striking a balance. This is the balance between freedom and authority (see Gadotti, 1996. p. 53).

One of the themes that recurs throughout Freire's later work is the need for teachers to extend their work outside the sphere of the classroom, adult education setting, cultural circle or university and to connect with what goes on in the "public sphere".

\footnotetext{
In reality, when you work toward convincing the students, your ellort is in relation to a political victory that takes place outside of the university. Your act of convincing seeks to obtain support for your greater dream, not simply to be a good professor. If you accept that your teachings do not go beyond the walls, in my opinion you are making a mistake, that of elitism. You will be a Marxist who only knows Marx through books and who restricts Marxism to the classroom, outside of which he [sic] clains to be only an academic. This is denying Marx and denying education itself. (Freire, in Escobar et al., 1994, p. 37).
}

It was important for Freire to engage with the system and not shy away from it for fear of co-optation (see, for instance, the discussions in Horton and Freire, 1990 and Escobar et al., 1994 on this). In a conception denoting strong Gramscian undertones, the system was, for Freire, not monolithic. On the contrary, it offered spaces for counter-hegemony, for "swimming against the tide" (see Freire, in Escobar et al., 1994, pp. 31-32). Teachers and other social actors who see themselves as tranformative intellectuals and cultural workers 
should, to use a popular Freire phrase, "be tactically inside and strategically outside" the system. Here the theme of social movements is given prominence (a recurring theme in most of, if not all, his books from the mid eighties onward), attesting to Freire's recognition of the role of social movements as agents of change. The emergence of MST in Brazil and other movements elsewhere, including Europe. captured his imagination. He himself was part of, and indeed contributed to, a movement striving for an important process of change, of radicalization, within an important institution in Latin America and beyond... the church. Cardinal Arns told Carmel Borg and me, in São Paulo, something to the effect that Paulo Freire changed not only people's lives but also the church. ${ }^{13}$ Furthermore, Freire strove to bring social movements and state agencies together in São Paulo when Education Secretary there (see O'Cadiz et al., 1997).

The idea of a wide public sphere in which teachers must engage is in keeping with Freire's insistence that education should not be romanticized. Education does not change things on its own and should therefore not be given powers it does not have (see Freire, in Shor and Freire, 1987, p. 37). This contention by Freire should have put paid to the by now hackneyed criticism that "conscientisation" does not necessarily lead to change, a criticism that persisted in the $90 \mathrm{~s}$ (eg. Elias, 1994).

Of course, the idea of educators working within the contexts of social movements has gained prominence in the literature on transformative education, most particularly in the area of adult education (for a critical review of this, see Foley, 1999 . pp. 135-138). Here, the discussion centres around a very non-Gramscian use of the concept of "civil society." In his later work, however, Freire sought to explore the links between movements and the State (Freire, 1993) and, most significantly, movements and party, a position no doubt influenced by his role as one of the founding members of the PT. The latter is quite interesting given the criticism often levelled at social movement theorists, namely that they tend to ignore the role of the party (see Holst, 1999). In a position which echoes Raymond Williams, Freire argues that the party for change, committed to the subaltern, should allow itself to learn from and be transformed through contact with progressive 
social movements. It had "to reconnect with the general interest" (Mcllroy, 1993, p. 277), as John Mcllroy puts it, with reference to Raymond Williams' ideas in this regard. Williams was here referring not only to the party but to all organisations traditionally associated with the working class.

One important proviso Freire makes, in this respect. is that the party should do this "without trying to take them over." Movements, Freire seems to be saying. cannot be subsumed by parties, otherwise they lose their identity and forfeit their specific way of exerting pressure for change. In terms of the links between party and movements. and with specific reference to the possible links between the PT and such movements as MST, Paulo has this to say:

Today, if the Workers Party approaches the popular movements from which it was born, without trying to take them over, the party will grow; if it lurns away from the popular movements. in my opinion. the party will wear down. Besides. Ihose movements need to make their struggle politically viable. (Freire, in Escobar et al., 1994. p. 40).

Freire's later work and biographical elements help to elucidate themes which have always been connected with his work. The major contribution here is that of rendering the concepts more concrete. The theme of connecting with the lifeworlds of the learners, the "concrete knowledge of the reality" of the community in question (Freire. 1998b, p. 122) as the basis for genuine democratic teaching, is a recurring one. "Educands' concrete localization is the point of departure for the knowledge they create of the world" (Freire, 1994, p. 85). It is the starting point, however, and not the be all and end all of the pedagogical encounter. (See Freire. 1994, p. 84). In remaining there and not moving beyond (through co-investigation of the object of inquiryl, one would be engaging in "basism", the romanticization (or "mythification") of the vernacular. We must start, however, by connecting with the learners" "concrete context" (Freire, 1998a, p. 78), including the child's dreams (in the case of young learners) or possibly nightmares (Freire repeats, throughout at least three of his last books, the response of a child from the slums who states: "I do not have dreams, only nightmares"). To ignore this is "elitism" (Freire. 1994, p. 84).

The central theme of praxis constitutes the leitmotif in Freire's later work (see Ninth letter in Freire, 1998a, pp. 75-85; 
Freire, 1998b, p. 44), as in all of his work. He regards exile as a form of praxis, in the sense of enabling Freire and others to gain critical distance from their native land, to view it in a critical light. This can lead to transformative action. This is a recurring theme in his later works (see Freire, 1997a, pp. 67-72). Perhaps one of the first instances is provided in his 1989 exchange with fellow Latin American exile, Antonio Faundez (Freire and Faundez, 1989). There were many experiences to which Freire was exposed during exile, including his involvement with workers' education circles in Italy and Spain (see Freire, 1994) as well as the postcolonial experiences in Portugal's former African colonies (see Freire, 1978; Freire and Faundez, 1989; Freire and Macedo, 1987). This notwithstanding, exile meant for Freire a cruel severing from his Brazilian roots during the best years of his life, "when he was at the peak of his activist energies, intimately linked to a society roused for transformation." (Shor, 1998, p. 78).

This brings the age factor into consideration. Of course, Freire raises the issue of "returning old" in Pedagogy of the Heart (Freire, 1997a, p. 72), affirming how his return was a form of reinvigoration: "I was returning hopeful, motivated to relearn Brazil, to participate in the struggle for democracy...." (Freire, 1997 a, p. 72). Given the "lost years", he had to feel young to be able to make the most, in terms of activism, of his remaining years. The more recent works are full of accounts of this later activism which was jolted by the loss of his beloved Elza in the fall of 1986 and possibly reinvigorated through his ten years of marriage to Nita. These are described as ten years of love and passion and are captured by Nita Freire in Nita $e$ Paulo. Cronicas di Amor, planned to be released in English. The sense of "making up for one"s lost years" is what runs through these later works that project the image of Freire as a role model for people in their Third Age: "As I write this at seventy five, I continue to feel young, declining-not for vanity or fear of disclosing my age-the privilege senior citizens are entitled to, for example, at airports.... People are old or young much more as a function of how they think of the world, the availability they have for curiously giving themselves to knowledge." (Freire, 1997a, p. 72).

Love and Humility continue to remain recurring themes in his later work. He constantly exhorts teachers to engage in their 
work with humility, tolerance and love (see Freire, 1995a: Freire, 1998a, pp. 39-41: Freire, 1998b, p. 65). Love was always a key feature of his work. It reflects several key elements in the genesis of Freire's work, not least its Christian undertones. Love is also, for Freire, one of the emotional elements that drives a person forward in any humanizing activity. For Freire, there could be no teaching and other hunlanizing activity without love: "I could never think of education without love and that is why I think I am an educator first of all because I feel love." (Freire, in McLaren, 1997b, p. 37) The concept of love becomes arguably even stronger in his later work. Paulo states, in response to a question, by Carlos Alberto Torres, regarding his legacy, that he would like people to say the following: "Paulo Freire was a man who loved, who could not understand a life existence without love and without knowing. Paulo Freire lived, loved and he tried to know" (Freire, 1995b, p. 1811. Strongly connected with Love is the value of Humility. For all their competence and authority, teachers must be humble to relearn that which they think they already know from others, and to connect, through learning ("there is no teaching without learning"--Freire, 1998b, pp. 29-48), with their learner's lifeworlds

"Tolerance" is a word which strikes me as being a trifle condescending and I would much prefer the term "solidarity" in this context. Solidarity becomes an important issue in Freire's writings in the late eighties and nineties, which stress the need for persons to gain greater coherence throughout life (see Freire, 1998b, p. 58). The quest for life and for living critically becomes an ongoing quest for greater coherence as a human being-an elaboration on his earlier modernist contention that a person's ontological vocation is that of becoming "fully human". Gaining coherence, for Freire, entails gaining greater awareness of one's "unfinishedness" (Freire, 1998b, pp. 51, 66) and one's "multiple and layered identities" (Freire, 1997b). These identities are often contradictory, rendering a person oppressed in one context and an oppressor in another, in the latter case being a manifestation of the "oppressor within", a very important theme in his most celebrated work. This makes nonsense of the criticism, often levelled at Freire in US circles, that he fails to recognise that one can be oppressed in one situation and an oppressor in 
another and that he posits a binary opposition between oppressor and oppressed. If anything, the relations between oppressor and oppressed have always been presented by Freire as dialectical rather than as binary opposites (see Allman, 1999, pp. 88-89, for an insightful exposition in this regard).

Gaining greater coherence entails getting to know and engaging in solidarity with, as well as learning from, the "other". This theme becomes all the more pertinent given the quest, among democratic educators/cultural workers, to press for a revolutionary, critical form of multiculturalism (see McLaren, 1997a).

The theme of gaining coherence is a recurring one in his later work, especially in a brilliant piece which constitutes a response to a number of commentators on his work (Freire, 1997b). It reflects a recognition, on Freire's part, that forms of domestication can emerge from an ostensibly emancipatory practice. The contradictions arising from our multiple and layered subjectivities render this a constant possibility. Rather than indulging in a nihilistic renunciation of attempts at an empowering pedagogical practice, Freire sees this as one of the strengths of critical pedagogy, the approach to pedagogy which Henry Giroux associates with Paulo Freire. Giroux states: “... I think that anyone who took up that field, in some way, had to begin with him [Freire] whether they liked him or not." (Giroux, in Torres, 1998, p. 141). Being based on praxis, on the recognition of our "unfinishedness" as human beings and as pedagogues and on the constant need to engage in annunciation and denunciation, genuine critical pedagogy involves an ongoing struggle of reflecting on oneself, on the social collectivity involved and on the pedagogical practice. This is done with a view to transformative action-action intended to enable one to confront one's contradictions to become less "unfinished"/incomplete, less incoherent. This emerges from the piece by Freire in Mentoring the Mentor, but I would submit that it was always present in his work. It is implied in Freire's exhortation, in Pedagogy of the Oppressed, to recognise the presence of and to confront the "oppressor within" (the "oppressor consciousness"-the internalization of the oppressor's image).

The response to commentators in Mentoring the Mentor is a piece which throws into sharp focus Freire's later concerns 
with forms of oppression that are not just related to class issues but which also include race and gender. As he states, time and again in his later works, one cannot explain anything under the sun in terms of the class struggle. At the same time, he has often argued that Perestroika did not have the power to suppress the existence of social class (Freire, 1991). With respect to his discussions on race, gender and other lorms of identity, Freire's contact with the North American critical pedagogical milieu strikes me as having been instrumental. Collaborators like Donaldo Macedo and the contributors to the Mentoring the Mentor volume have pressed him hard on these issues, as have writers like Kathleen Weiler (1994), through her criticisms of Freire's writings, and the largely sympathetic bell hooks (hooks, 1993).

One ought to refer here to his discussions on machismo (Freire and Macedo, 1993, 1995; Freire, 1994, 1996) and racism (see Freire and Macedo, 2000). In the latter case, he and Macedo condemn the scientism that is often a hallmark of Eurocentric regimes of truth. Having said this, I winced at his statement, "I am too a woman" (Freire, in Freire and Macedo, 1993, p. 175), concerning solidarity with women. I feel that there is a limit to which we men can be at one with women in their struggles, not being able to feel the pain of this specific form of oppression (Mayo, 1999, p. 115). This notwithstanding. Freire has gone to great lengths to rectify the totalising gender discourse of his earlier works, thus responding positively to the numerous American feminists who took issue with him on this matter. Perhaps, a talking book in English between Freire and a woman or a person of colour would not have been out of place in this context. bell hooks expressed her desire to engage in such a book with Freire (hooks, 1993) but, for some reason or other, this never materialised.

Perhaps, the greatest contribution of Freire's later works lies in the demonstration of the ability to introduce concepts connected with popular education in the context of a municipal state school system (see Freire, 1991, 1993, 1997a, 59-63: Saul, 1995). The theme of a democratic, popular public school is a recurring one in his works. It is a community school which is not the exclusive domain of teachers and educational administrators but which is open to many other people with a stake in education, including parents and other 
guardians, community representatives, students, janitors, cooks, etc. And all those who are in contact with children in schools are to be formed as educators, including the cooks and janitors (see Freire, 1991). Those educators who are involved worldwide in democratising the face of the public schools and education in general, would do well to read Freire's works on the subject of "changing the face of the schools." ${ }^{14}$ This process might have been interrupted in São Paulo following the PT's loss of government there but continues in at least one other city in Brazil, Porto Alegre in Rio Grande do Sul. The ideas connected with the São Paulo reforms remained influential, certainly in other parts of Brazil. This renders such books as Pedagogy of the City and Pedagogy of Hope of great importance to cultural workers, policy makers and educational administrators who work towards the democratisation of the public educational system. If one looks at the printed literature (in English) connected with the Porto Alegre experience, one can immediately detect the Freirean influence. The spirit of his São Paulo reforms runs through this municipal project in Rio Grande do Sul (City Secretariat of Education of Porto Alegre, 1999). Pedagogy of the City strikes me as a publication worth recommending for any educational policy or educational administration course. Of course, this raises the question regarding spaces available for such reforms within the context of the hegemonic neo-liberal state whose funding policies are closely monitored by the IMF and the World Bank. And, of course, as Freire would argue, these experiences cannot be transplanted but have to be reinvented in the contexts in question.

One final theme, emerging from Freire's later works, which requires underlining in this review, is that of postcolonialism. This is more than just a theme. Postcolonialism, or more appropriately, anti-colonialism, is a project to which Freire has always given voice. His early work, including his most famous book, is rooted in the history of the Brazilian colonial experience, while the Guinea Bissau, Cape Verde and Sao Tome \& Principe writings (see Freire, 1978; Freire and Macedo, 1987; Freire and Faundez, 1989) reflect a concern with a national, postcolonial educational strategy for "decolonizing the mind". In his later work, the issue of colonialism is addressed in many ways. One gathers that Freire uses the 
term "colonial" in the broader Foucauldian sense of "colonized subject". One obvious example here is his reference to the oppression of women, through sexist discourse and enfleshment in "concrete practices," as "colonial" (Freire, 1994, p. 67). He also deals, in his work, with the legacy of colonial structures and thinking in countries that went through long historical periods of foreign colonial occupation/domination. For instance, he regards the policies affecting the establishment of priorities with regard to salaries in Brazil as a colonial hangover (Freire, 1998a, p. 37). The theme of colonialism was also developed in a manner that is in keeping with the situation of most countries worldwide-neo-colonialism in its most predatory (McLaren, 1995) form. For Freire, the struggle for decolonization had to be an ongoing one. Analyzing Freire's work in relation to that of Ernesto (Che) Guevara, Peter McLaren underlines:

\footnotetext{
Freire acknowledges that decolonization is a project that knows no endpoint, no final closure. It is a lifetime struggle that requires counterintuitive insight, honesty, compassion, and a willingness to brush one's personal history against the grain of "naive consciousness" or commonsense understanding. After engaging the legacy of revolutionary struggles of the oppressed that has been bequeathed to us by Freire, it remains impossible to conceive of pedagogical practice evacuated of social critique. Freire has left stratified deposits of pedagogical insight upon which the future development of progressive education can-and must--be built. There is still reason to hope for a cooperative pedagogical venture among those who support a Freirean. class based, pedagogical struggle, feminist pedagogy, or a pedagogy informed by queer theory and politics, that may lead to a revival of serious educational thinking in which the category of liberation may continue to have and to make meaning. (McLaren, 2000, p. 170)
}

It is fitting therefore to conclude this essay the way it started. In confronting the fatalism of neoliberalism. Freire had embarked on his latest attempt to confront the most recent form assumed by colonialism. For colonialism is a constant feature of the capitalist mode of production which is characterised by restructuring and the search for new markets. Colonialism takes on different forms and the one it is assuming at present is predicated on neoliberalism with its concomitant ideology of the marketplace.

The fatalism of neoliberalism (Araújo Freire, 1997, p. 10) is an important theme in Freire's later English language books. 
He speaks of the nihilism of what he calls reactionary postmodernity which denies people the chance to dream of a better world. The kind of nefarious and insidious thinking that becomes the subject of his attack is what he terms the ideological negation of ideology: "the ideology of ideological death." (Freire, 1998a, p. 14) Freire's thinking in this regard, predicated on the sense of agency and the constant unmasking of ideologies characterised by denúncia and anúncio, strikes me as being in keeping with what Frei Betto anticipates to be "a world movement to rescue utopias." (Betto, 1999, p. 45). In Betto's words:

This is exactly it: it is an ideology that preaches the death of ideology. I think this is all nonsense. because human beings need dreams, need utopia and there is no ideology, no system that can stop this force. Dostoyevski was right when he said: 'The most powerful weapon of a human being is his (sic) conscience' and this nobody can destroy. I think it ridiculous when they preach that there is no ideology any more, in order to be able to state that the only ideology is the neo-liberal one. I think that it is a matter of time before we witness the eruption of a world movement to rescue utopias.

Of course, in these later works, Freire seems to be expressing his immediate reactions to an ideology that is fatalistic and contradictory. These reactions are sporadic and were yet to be developed into a coherent and systematic work, precisely the kind of work he was contemplating at the time of his death. Freire expresses his anger at this ideology in Letters to Cristina, where he argues:

We therefore don't have to continue to propose a pedagogy of the oppressed that unveils the reasons behind the facts or that provokes the oppressed to take up critical knowledge and transformative action. We no longer need a pedagogy that questions technical training or is indispensable to the development of a professional comprehension of how and why society functions. What we need to do now, according to this astute ideology, is focus on production without any preoccupation about what we are producing. who it benefits, or who it hurts. (Freire. 1996. p. 84]

And yet, as I have argued elsewhere (Mayo, 1999), the scenario of general impoverishment, often bordering on destitution, in various parts of the world, especially those under the sway of structural adjustment programs, with an ever widening 
gap between North and South, necessitates that we remain preoccupied with how (an addition to Freire's phrase) and "what we are producing, who it benefits, or who it hurts" (p. 5). We need a pedagogy concerned not only with the above but which, in response, enables us to imagine and strive collectively toward the realization of a world which can and ought to be different, a world governed by life centred, rather than market driven, values (See Miles, 1996; Miles, 1998, p. 256). The quest for such a pedagogy by Freire, the anticolonial or postcolonial pedagogue par excellence, is in keeping with his long search for the refinement of pedagogical approaches that confront colonialism in its different forms (see Giroux, 1993, 1998). Freire was exploring the ingredients for what would have been his next major and timely book project. Alas, it was not to be!

One wonders whether his new work would have extended beyond the anthropocentric framework which characterizes much of his output and that of many other authors whose work he inspired, including myself. The point concerning Freire's "anthropocentrism" is raised also by Stanley Aronowitz (1998b, p. 11). In confronting neo-liberalism by positing life centred values in contrast to market driven ones, we require a radicalism which extends beyond the realm of social relations, to embrace the larger domain of human-earth relationships. There is need for the Eco-prefix to be added to the title of any of the radical-isms we embrace, as in Ecofeminism (see Mies and Shiva, 1993). The Eco-prefix is not an "add on" but an integral feature of the struggle involved. With regard to human-earth relationships, we can draw sustenance from the works of people like Metchild Hart (1992), Maria Mies and Vandana Shiva (1993). Among the most recent works, I would cite that by Edmund O'Sullivan (1999) and the one by Francisco Gutierrez and Cruz Prado (2000), the term Ecopedagogia being used in the latter case. It is also heartening to note that the Instituto Paulo Freire in São Paulo, officially founded on September 1, 1992, has a programme in Ecopedagogy, intended to promote the construction of a planetary citizenship, and is working assiduously towards the creation of an Earth Charter (Carta da Terra), something similar to the Universal Declaration of Human Rights (IPF, 2000, pp. 11, 12). 
O'Sullivan forcefully expresses the point, concerning the anthropocentric nature of much critical pedagogy, in his highly inspiring book:

Probably one of the most prominent omissions in the critical pedagogical approaches to education at this juncture of its formulations is its lack of attention to ecological issues. My major criticism of a critical perspective is their preeminent emphasis on inter-human problems frequently to the detriment of the relations of humans to the wider biotic community and the natural world. The general direction of critical perspectives is toward anthropocentrism. The criticism of anthropocentrism is by no means a reason for dismissal of the vital concerns that critical perspectives pose for contemporary education. These issues must be taken forward and fused into wider biocentric concerns. (O'Sullivan, 1999, pp. 63, 64).

This requires our building on and going beyond the struggle commenced by Freire. Freire has however thrown the gauntlet. It is left to others to pick it up, reconstituting his work and ideas in the process. For, once again, these cannot be simply "transplanted" across time, geographical boundaries and different struggles, but need to be "reinvented".

\section{Notes}

1 'Reflections from a 'Third Age Marriage': a pedagogy of reason, hope and passion Ana Maria (Nita) Araújo Freire interviewed by Carmel Borg \& Peter Mayo" unpublished manuscript. The interview took place in São Paulo, April, 1998. Transcribed by Frei Sergio Abreu and translated by Lilia Azevedo. Frei Joao Xerri acted as interlocutor throughout the interview.

2 Literal translation: Movement of Rural Workers without Land. The abbreviated title is Movimento dos Sem Terra (MST-Movement of Landless Peasants).

3 See for instance the following compact disks: Terra by Chico Buarque. MST, 1997: Arte em Movimento (19 pieces of music and a poem). interpreted by Ires Escobar. Marcos Monteiro, Ze Pinto. Ze Claudio and Protasio Prates, Movimento dos Trabalhadores Rurais Sem Terra.

4 Indebted to Nita Freire for this information. Same source as in endnote 1.

5 It was published in the mid-1980s by Conadep, the Comision Nacional sobre la Desaparicion de Personas (literal translation: National Commission concerning Disappeared Persons), led by one of Argentina's most important public intellectuals, writer Emesto Sabato. 1 am indebted, for this information, to my good friend, Daniel Schugurensky, from the Department of Adult Education. Community Development and Counseling Psychology at the Ontario Institute for Studies in Education/University of Toronto. 
6 Carmel Borg and I are indebted to Cardinal Arns for this informationprivate conversation. in the presence of Frei Joan Xerri, in the Sacristy of São Paulo Cathedral, April, 1998. The point was confirmed to nie by Nita Freire at the Pedagogy/Theatre of the Oppressed Conference. New York. June. 1999.

7 I am indebted to Lilia Azevedo lor confirming and clarifying facts surrounding this document and other matters referred 10 in this paper. I am also indebted to Frei Joao Xerri for having picked up lots of information, referred to in this paper, from him.

8 Source as in endnote 1.

9 In endnote 5. in Mayo. 1997a. p. 369. I mention that my good triend and colleague. Mary Darmanin, had reminded me of this most important feature of Freire's work. Like me, she read Freire in translation.

10 I am indebted for this point to David $W$. Livingstone, from the Department of Sociology and Equity Studies in Education at the Ontario Institute for Studies in Exlucation/University of Toronto.

11 At the risk of sounding apologetic, I would like to reiterate, in fairness sake, the point I make elsewhere (Mayo, 2000). For my money, Frank Youngman (1986) provides the finest text in English to date for a comprehensive analysis of the potential contribution of historical nuaterialist tenets to the development of a socialist approach to adul education. The book contains. among other things. a brilliant and lucid second chapter on "Marxism and Learning".

12 Taylor's text is full of erudition. extremely informative and quite thoughtprovoking. $1 t$ challenges freire-inspired adult educators to reflect critically on their practice and recognise the contradictions that emerge (Mayo. 1993. p. 283). Elias' strength lies in his discussion on the Marxist humanist and theological underpinnings to Freire's work. See Mayo (1996) on this.

13 Conversation with Cardinal Arns mentioned in endnote 5.

14 The phrase derives from Nita Freire and is taken from the source in endnote 1 .

\section{References}

Allman. P. (1999), Revolutionary Social Transformation: Democratic Hopes, Political Possibilities and Critical Education. Massachusetıs: Bergin \& Garvey.

Allman, P., Mayo, P., Cavanagh, C., Lean Heng. C. and Haddad, S. (1998), "... The Creation of the World in which It Will Be Easier to Love" in Convergence (A Tribute to Paulo Freire), 31. 9-16

Araújo Freire (1997). "A Bit of My Life with Paulo Freire" in Taboo: The Journal of Cullure and Education, 2, 3-11.

Araújo Freire, A. M. (1998). "Paulo Freire: To touch, to look, to listen" in Convergence (A Tribute to Paulo Freire), 31, 3-5.

Aronowitz. S. (1998), "Intreduction," in Freire, P.. Pedagogy of Freedom. Ethics. Democracy and Civic Courage. (pp. 1-19), Lanham. Boulder. New York \& Oxford: Rowman \& Litllefield. 
Betto, F. (1999), "Liberation Theology 'No longer a ghetto in the Church,"' (Frei Betto interviewed in São Paulo by Dr. Carmel Borg and Dr. Peter Mayo) in The Sunday Times (Malta), 17/10/99, 44-45.

Betto, F. and Freire. P. (1986), Una Scuola Chiamata Vita (A School Called Life). Bologna: E.M.I.

Borg. C. and Dharsey, Z. (1994), "View from the Margins-Reflecting on Issues of Global Transformation" in Trans/forms: Insurgent Voices in Education, 1, 20-36.

City Secretariat of Education of Porto Alegre (1999), Cycles of Formation: Politic-Pedagogical Proposal for the Citizen's School, Porto Alegre: Prefeitura de Porto Alegre.

Coben. D. (1998). Radical Heroes: Gramsci. Freire and the Politics of Adult Education, New York: Garland Press.

Elias, J. (1994), Paulo Freire: Pedagogue of Liberation, Florida: Krieger.

Escobar, M., Fernandez, A. L. and Guevara-Niebla, G. with Freire, P. (1994). Paulo Freire on Higher Education: A Dialogue at the National University of Mexico, Albany: SUNY Press.

Fischman, G. (1999), Review ol Teachers as Cultural Workers: Letters to Teachers Who Dare Teach, in Comparative Education Review, 43, 556-559.

Foley, G. (1999), Learning in Social Action: A Contribution to Understanding Informal Education, London and New York: Zed Books.

Freire. P. (1970). Pedagogy of the Oppressed. New York: Seabury Press.

Freire, P. [1978). Pedagogy in Process: The Letters to Guinea Bissau, New York: Continuum.

Freire, P. (1985), The Politics of Education, Massachusetts: Bergin and Garvey.

Freire, P. (1991), "The Work of Paulo Freire as Secretary of Education in Sāo Paulo" in Educational Policy and Social Change in Brazil, AERA, Chicago, Teach 'em Inc. (audio tape).

Freire, P. (1993), Pedagogy of the City, New York: Continuum.

Freire, P. (1994), Pedagogy of Hope, New York: Continuum.

Freire, P. (1995a), "The Progressive Teacher" in M. de Figueiredo-Cowan and D. Gastaldo (eds.), Paulo Freire at the Institute, (pp. 17-24), London: Institute of Education-University of London.

Freire, P. (1995b), "Learning to Read the World: Paulo Freire in conversation with Carlos Torres" in Torres, C. A. (ed.). Education and Social Change in Latin America, (pp. 175-181), Melbourne: James Nicholas Publishers.

Freire, P. (1997a), Pedagogy of the Heart, New York: Continuum.

Freire, P. (1997b), "A Response" in Freire, P., with Fraser, J. W., Macedo, D.. McKinnon, T., and Stokes. W. T. (eds.). Mentoring the Mentor: A Critical Dialogue with Paulo Freire. (pp. 303-329), New York: Peter Lang.

Freire, P. (1998a), Teachers as Cultural Workers: Letters to Teachers who Dare Teach, Boulder, Colorado: Westview Press.

Freire. P. (1998b). Pedagogy of Freedom: Ethics. Democracy and Civic Courage, Lanham, Boulder, New York \& Oxford: Rowman \& Littlefield. 
Freire, P. and Betto, F. (1985), Essa Escola Chamada Vida, São Paulo: Atica.

Freire, P. and Faundez, A. (1989), Learning to Question: A Pedagogy of Liberation, Geneva: World Council of Churches.

Freire, P. and Macedo, D. (1987), Literacy: Reading the Word and the World. Massachusetts: Bergin and Carvey.

Freire, P. and Macedo. D. (1993), "A Dialogue with Paulo Freire" in McLaren, P. and Leonard, P. (eds.), Paulo Freire: A Critical Encounter, (pp. 169-176), London and New York: Routledge.

Freire, P. and Macedo, D. (1995). "A Dialogue: Culture. Language and Race", Harvard Educational Review, 65, 377-402.

Freire, P. and Macedo, D. (2000). "Scientism as a form of Racism" in Steiner. S.. Krank. M. McLaren, P and Bahruth. R. (eds.). Freirean Pedagogy. Praxis and Possibilities: Projects for the Neu Millenium. (pp. 33-40), New York: Falmer Press.

Freire, P., with Fraser, J. W., Macedo. D., McKinnon, T, and Stokes W. T. (eds.) (1997). Mentoring the Mentor: A Critical Dialogue with Paulo Freire. New York: Peter Lang.

Gadotti. M. (1994), Reading Paulo Freire: His Life and Work, Albany: SUNY Press.

Gadotti. M. (1996), Pedagogy of Praxis: A Dialectical Philosophy of Education. Albany: SUNY Press

Giroux. H. (1993), "Paulo Freire and the Politics of Postcolonialism" in McLaren, P. and Leonard, P. (eds.). Paulo Freire. A Critical Encounter, (pp. 177-188). New York \& London: Routledge.

Giroux, H. (1996). Disturbing Pleasures, London and New York: Roulledge.

Gutierrez. F. and Prado. C. (2000). Ecopedagogia e Citiadinanza Planetaria. Bologna, E.M.1

Hart, M. (1992), Working and Educating for Life: Feminist and International Perspectives on Adult Education. London and New York: Routledge.

Holst, J. D. (1999). "The Aflinities of Lenin and Gramsci: implications for radical adult education theory and practice" in Intemational Journal of Lifelong Education. 18,407-421.

hooks, b. (1993). "bell hooks Speaking about Paulo Freire: The Man, His Works" in McLaren. P. and Leonard, P. (eds.). Paulo Freire, A Critical Encounter, (pp. 146-154). New York \& London: Routledge.

Horton, M. and Freire, P. (1990). We Make the Road by Walking: Conversations on Educution and Social Change. Philadelphia: Temple University Press.

IPF (2000), Institutional Curriculum (Curriculo Institutional) 2000: Project. Profile and Trajectory (Projeto, Perfil e Percurso). Sao Paulo, Instituto Paulo Freire

Martin, D. (1998), "Learning from the South" in Convergence (A Tribute to Paulo Freire). 31, 117-127.

Mayo, P. (1993). Review of The Texts of Paulo Freire by Paul V. Taylor, in Adults Learning. 4, 283.

Mayo, P. (1996). Review of Paulo Freire. Pedagogue of Liberation by John Elias, in Convergence, 29, 63-68.

Mayo. P. (1997a), "Tribute to Paulo Freire (1921-1997)" in International Journal of Lifelong Education. 16, 365-370. 
Mayo. P. (1997b), "Reflections on Freire's Work: A Maltese Contribution" in Taboo. The Journal of Culture and Education, 2, 120-123.

Mayo, P. (1999), Gramsci, Freire and Adult Education: Possibilities for Transformative Action, London \& New York: Zed Books.

Mayo, P. (2000). "Marxism's Impact on Adult Education" in Educational Practice and Theory, 22, (forthcoming).

McLaren. P. (1995), Critical Pedagogy and Predatory Culture. Oppositional Politics in a Postmodern Era, London and New York: Routledge.

McLaren, P. (1997a), Revolutionary Multiculturalism: Pedagogies of Dissent for the New Millenium, Boulder Colorado: Westview Press.

McLaren, P. (1997b), "Paulo Freire's Legacy of Hope and Struggle" in Taboo: The Journal of Culture and Education, 2, 33-38.

McLaren. P. (2000), Che Guevara, Paulo Freire, and the Pedagogy of Revolution. Boulder. Colorado: Rowman and Littlefield.

McLaren, P. and Da Silva, T. T. (1993), "Decentering Pedagogy: Critical Literacy, Resistance and the Politics of Meaning" in McLaren, P. and Leonard, P. (eds.), Paulo Freire: A Critical Encounter, (pp. 47-89), New York \& London: Routledge.

McLaren, P. and Lankshear, C. (eds.) (1994), Politics of Liberation: Paths from Freire, New York and London: Routledge.

McLaren. P. and Mayo. P. (1999). "Value Commitment. Social Change and Personal Narrative" (Peter Mayo interviewed by Peter McLaren), in International Journal of Educational Reform, 8, 397-408.

Mcllroy, J. (1993), "Community, Labour and Raymond Williams" in Adults Learning, 4, 276-277.

Miles, A. (1996), Integrative Feminisms: Building Global Visions. 1960s1990s, New York and London: Routledge.

Miles. A. (1998), "Learning from the Women's Movement in the Neo-Liberal Period" in Scott., S. M., Spencer. B. and Thomas, A., Learning for Life: Canadian Readings in Adult Education, (pp. 250-258) Toronto: Thompson Educational Publishing, Ine.

Mies, M. and Shiva, V. (1993), Ecoferninism, London: Zed Books.

O'Cadiz, P., Wong, P. L. and Torres, C. A. (1997). Education and Democracy: Paulo Freire, Social Movements and Educational Reform in São Paulo. Boulder: Westview Press.

O'Sullivan, E. (1999), Transformative Learning: Educational Vision for the 21 st Century, London, Toronto and New York: Zed Books and University of Toronto Press.

Roberts. P. (2000). Education, Literacy. and Humanization: Exploring the Work of Paulo Freire, Westport, Connecticut: Bergin \& Garvey.

Saul. A. M. (1995), "Municipal Educational Policy in the City of São Paulo, Brazil (1988-1991)" in Torres, C. A. (ed), Education and Social Change in Latin America, (pp. 155-162). Melbourne: James Nicholas Publishers.

Shor. I. (1998), "The Centrality of Beans: Remembering Paulo," in Convergence (A Tribute to Paulo Freirel. 31, 75-80.

Shor, I. and Freire, P. (1987). Pedagogy for Liberation: Dialogues on Transforming Education, Massachusetts: Bergin and Garvey.

Taylor, P. V. (1993). The Texts of Paulo Freire. Buckingham: Open University Press. 
Torres, C. A. (1994), "Paulo Freire as Secretary of Education in the Municipality of São Paulo" in Comparative Education Review. 38, 181-214.

Torres, C. A. (ed.) (1995), Education and Social Change in Latin America, Melbourne: James Nicholas Publishers.

Torres, C. A. (1998), Educaion. Power, and Personal Biography: Dialogues with Critical Educators, New York and London: Routledge.

Weiler. K. (1991), "Freire and a Feminist Pedagogy of Difference" in McLaren, P. and Lankshear. C. (eds.). Politics of Liberation: Paths from Freire (pp. 12-40). New York and London: Routledge.

Youngman. F. (1986), Adult Education and Socialist Pedagogy, Beckenham: Croom Helm. 